Omni-Akuatika, 12 (3): 1-10, 2016
ISSN: 1858-3873 print / 2476-9347 online
Research Article
Scientific Communication in Fisheries and Marine Sciences - 2016

\title{
Status Pengelolaan Sumberdaya Ikan Demersal Sekitar Pantai di Kabupaten Indramayu, Jawa Barat
}

\author{
Gatot Yulianto ${ }^{1}$, Kadarwan Suwardi ${ }^{2}$, Luky Adrianto ${ }^{2}$, Machfud ${ }^{3}$ \\ ${ }^{1}$ Mahasiswa Program Studi Pengelolaan Sumberdaya Alam dan Lingkungan, IPB \\ ${ }^{2}$ Staf Pengajar Departemen Sumberdaya Perairan, Fakultas Perikanan dan IImu Kelautan, IPB \\ ${ }^{3}$ Staf Pengajar Departemen Teknologi Industri Pertanian, Fakultas Teknologi Pertanian, IPB
}

Corresponding author*:gyo_65@yahoo.com

\begin{abstract}
The status of fish resources in management fisheries context is important to be known for setting resources policy in order to ensure continuity of fish stock and harvest. Estimating the level of sustainable catches and economic rent by using surplus production approach and Gordon-Schaefer bioeconomic analysis then comparing the actual condition, it will point to level of resource exploitation and level of resource degradation. The management of demersal fish around the beach in Indramayu Regency which is characterized by open access resource indicate the status of the fish resource in a state of overfishing and degraded. Therefore, it is important for designing fisheries management policy by regulating the amount of fishing effort.
\end{abstract}

Keywords: demersal fish, bioeconomic analysis, overfishing, degradation

\section{Pendahuluan}

Aktivitas perikanan tangkap di laut mempunyai peranan penting dilihat dari kontribusinya terhadap pembangunan wilayah pesisir, mampu menyediakan protein ikani, menyerap tenaga kerja, memperoleh devisa negara melalui kegiatan ekspor serta meningkatkan pendapatan nelayan. Perikanan merupakan suatu sistem yang terdiri dari tiga komponen yang saling berinteraksi, yakni biota akuatik, habitat akuatik dan manusia sebagai pengguna sumberdaya tersebut (Lackey, 2005; Widodo dan Suadi, 2008). Dari pengertian tersebut dapat dikatakan bahwa keberadaan biota-ikan tidak terlepas dari kondisi habitatnya dan intervensi manusia yang direpresentasikan dalam penggunaan upaya penangkapan (unit effort). Aktivitas perikanan tangkap selama ini merupakan tempat bergantungnya kehidupan para nelayan, sehingga perlu dikelola sedemikian rupa, termasuk mengelola sumberdaya yang merupakan natural input bagi keberlanjutan usaha perikanan tersebut. Hilborn et al. (2005) menyatakan bahwa perikanan tangkap dikelola dalam rentang struktur institusi (kebijakan) yang luas dan termasuk juga pemberian hak atas sumberdaya ikan yang memperhatikan aspek moral-sosial (Lam and Pauly, 2010). Dalam konteks pengelolaan perikanan skala kecil, Cinner et al. (2013) menyatakan bahwa perlunya pendekatan institusi untuk mengatasi problem klasik perikanan seperti kegagalan dalam tata kelola, stock ikan yang collaps dan mengurangi kemiskinan.

Salah satu aspek penting dalam menetukan kebijakan/institusi pengelolaan adalah mengetahui kondisi sumberdaya ikan apakah sudah terdegradasi atau belum. Terkait dengan hal terebut, Fauzi dan Anna (2005) berpendapat bahwa informasi mengenai laju degradasi sumberdaya alam dapat dijadikan titik referensi (reference point) maupun early warning signal untuk mengetahui apakah ekstraksi sumberdaya alam sudah melampaui kemampuan daya dukungnya atau belum. Degradasi diartikan sebagai penurunan kualitas/kuantitas sumberdaya alam dapat diperbaharukan, misalnya sumberdaya ikan laut. Degradasi sumberdaya penting untuk diperhitungkan, sebab kebijakan pengelolaan yang mengabaikan degradasi sumberdaya alam akan menghasilkan kebijakan yang misleading. Dengan adanya informasi status sumberdaya diharapkan tidak terjadi mismanagement, seperti yang dikatakan Ruddle and Hickey (2008) bahwa terdapat mismanagement perikanan sekitar pantai di daerah tropik (tropical nearshore fishery) dalam mengimplementasikan program yang mengaplikasikan pendekatan dan model Barat. Kondisi perikanan di perairan laut Utara Jawa, termasuk perairan sekitar pantai di Indramayu sudah dinyatakan padat tangkap (Rahardjo, 1991), namun faktanya sampai saat 
ini masih banyak nelayan skala kecil yang melakukan kegiatan penangkapan ikan di perairan sekitar pantai Kabupaten Indramayu dengan menggunakan perahu motor tempel. Padat tangkap menjadi penyebab terjadinya tangkap lebih (overfishing) dan tangkap lebih itu sendiri merupakan salah satu penyebab terjadinya degradasi sumberdaya ikan. Tangkap lebih dapat diartikan sebagai jumlah ikan yang ditangkap melebihi jumlah maksimum ikan yang diperbolehkan untuk menjamin kelestarian stok di suatu perairan tertentu dan pada waktu tertentu. Nugroho et al. (2007) menyatakan bahwa besarnya kelimpahan sumberdaya telah mengalami degradasi secara terus menerus baik akibat tingginya tekanan penangkapan maupun penurunan kualitas habitat terutama di kawasan pantai.

Secara geografis, Kabupaten Indramayu berada pada posisi $107^{\circ} 52^{\prime}-108^{\circ} 36^{\prime}$ BT dan $6^{\circ} 15^{\prime}$ - $6^{\circ} 40^{\prime}$ LS. Kabupaten Indramayu memiliki luas $197.115 \mathrm{~km}^{2}$ atau $15,5 \%$ dari luas wilayah Provinsi Jawa Barat, sedangkan luas seluruh kawasan pesisir Kabupaten Indramayu adalah $68.703 \mathrm{~km}^{2}$ atau $35 \%$ dari luas total wilayah kabupaten. Pantainya membujur mulai dari Kecamatan Sukra hingga Kecamatan Karangampel, dengan panjang pantai sekitar $114 \mathrm{~km}$. Selain itu, Kabupaten Indramayu juga memiliki 3 (tiga) pulau kecil, yaitu Pulau Biawak, Pulau Gosong dan Pulau Candikian. Produksi perikanan tangkap dari Kabupaten Indramayu memberikan kontribusi terbesar terhadap produksi perikanan tangkap Propinsi Jawa Barat.

Perikanan skala kecil yang beroperasi di sekitar pantai (nearshore fishery) Kabupaten Indamayu masih cukup banyak. Perbedaan istilah perikanan skala kecil atau tradisional dengan perikanan skala besar atau industrial menunjuk pada ukuran besar kecilnya unit penangkapan atau operasi operasi penangkapan yang dalam istilah praktis dinyatakan sebagai ukuran perahu atau kapal. Jumlah nelayan di Kabupaten Indramayu Provinisi Jawa Barat pada tahun 2014 sebanyak 40,545 jiwa, 6,115 RTP dan jumlah armada perikanan (perahu) sebanyak 6,115 unit. Dari jumlah armada perikanan dan RTP tersebut terdapat 3.109 unit armada (sekitar $50.84 \%$ ) dan 1,659 RTP (sekitar 27.13\%) adalah armada dan RTP yang mengoperasikan perahu berbobot di bawah 5 GT yang merupakan nelayan skala kecil atau perikanan pantai (nearshore fishery). Alat tangkap pukat pantai, jaring klitik dan sero digunakan nelayan skala kecil dengan fishing ground di perairan sekitar pantai Kabupaten Indramayu.
Ikan demersal merupakan kelompok ikan yang habitatnya berupa lumpur atau lumpur berpasir. Ikan-ikan utama yang termasuk dalam ke dalam kelompok ikan demersal dapat dibagi menjadi dua jenis, yaitu ikan demersal besar dan ikan demersal kecil (Subani dan Barus, 1989; Broer et al., 2001). Jenis alat tangkap yang digunakan untuk menangkap ikan demersal adalah dogol, jogol, cantrang, jaring insang dasar/labuh (jaring klitik), rawai dasar, bubu dasar, pukat tepi/pantai (beach net), jaring arad (otter trawl) dan pancing tangan (Subani dan Barus, 1989) dan sero (Dwiponggo, 1987; Tenriware, 2005). Ikan demersal di sekitar pantai merupakan target utama usaha penangkapan ikan oleh nelayan Kabupaten Indramayu dengan menggunakan alat tangkap sero, jaring klitik dan jaring pantai.

Tujuan dari tulisan adalah mengetahui status pengelolaan sumberdaya ikan demersal sekitar pantai di Kabupaten Indramayu. Tulisan ini diharapkan dapat memberikan informasi awal bagi pembuatan kebijakan pengelolaan sumberdaya ikan demersal sekitar pantai secara berkelanjutan.

\section{Metode Penelitian}

\section{Metode pengumpulan data}

Jenis data yang dikumpulkan adalah data sekunder dan data primer. Data sekunder berupa jumlah alat tangkap (unit) dan jumlah hasil tangkapan dari tahun 2000 sampai dengan tahun 2014. Data sekunder diperoleh dari Laporan Tahunan Dinas Perikanan dan Kelautan Propinsi Jawa Barat dan Laporan Tahunan Dinas Perikanan dan Kelautan Kabupaten Indramayu. Data primer meliputi harga ikan dan biaya operasional penangkapan yang diperoleh melalui wawancara.

\section{Analisis Data}

\section{Analisis bioekonomi statik}

Meskipun merupakan model sederhana (konvensional) dan bersifat statis, model surplus produksi Schaefer (1954) cukup penting untuk memahami dasar-dasar pengelolaan perikanan dan degradasi sumberdaya. Untuk menghitung laju degradasi ikan demersal sekitar pantai di Kabupaten Indramayu dimulai dari persamaan dinamika stok ikan, dengan $\mathrm{h}$, $X_{t}$ dan $E_{t}$ masing-masing adalah produksi, stok ikan dan upaya penangkapan ikan (Effort), sebagai berikut :

$\dot{X}=F(X t)-h(X t, E t)$ 
Persamaan (1) dapat diartikan bahwa perubahan stok ikan merupakan perbedaan antara pertumbuhan 'logistik' ikan dengan aktivitas penangkapan ikan. Pertumbuhan logistik dan aktivitas penangkapan ikan masingmasing dinotasikan sebagai berikut :

$\mathrm{F}(\mathrm{Xt})=\mathrm{rXt}\left(1-\frac{\mathrm{Xt}}{\mathrm{K}}\right)$

$h(X t, E t)=q X_{t} E_{t}$

dimana : $r$ adalah laju pertumbuhan intrinsik, $\mathrm{K}$ adalah daya dukung lingkungan dan $q$ adalah koefisien daya tangkap. Dengan mensubstitusikan persamaan (2) dan (3) ke dalam persamaan (1) diperoleh persamaan :

$X=r X t\left(1-\frac{X t}{K}\right)-q X t E t$

Dengan mengasumsikan bahwa perubahan stok dalam kondisi keseimbangan jangka panjang adalah konstan, maka penyederhanaan persamaan (4) menjadi persamaan stok sebagai berikut :

$X=K\left(1-\frac{q E}{r}\right)$

Selanjutnya,

persamaan

disubstitusikan ke dalam persamaan (3), sehingga diperoleh persamaan produksi Schaefer yang dikenal sebagai persamaan yield-effort lestari sebagai berikut :

$h=q K E\left(1-\frac{q E}{r}\right)$

Selanjutnya, dari persamaan (6) tersebut dapat dihitung parameter biofisik $r, q$ dan $K$. Pengelolaan perikanan menurut keseimbangan statik model Schaefer yang terbaik adalah pada saat produksi lestari berada pada titik tertinggi kurva yield-effort (titik Maximum Sustainable Yield, MSY) dengan input yang dibutuhkan $E_{M S Y}$ dan titik tersebut diperoleh dari pemecahan turunan pertama terhadap effort dari persamaan (6) pada kondisi $\partial \mathrm{h} / \partial \mathrm{E}=0$, sehingga menghasilkan persamaan:

$$
E_{M S Y}=r / 2 q
$$

Dengan mensubstitusikan persamaan (7) ke dalam persamaan (6) selanjutnya dapat diperoleh hasil tangkapan pada tingkat MSY :

$\mathrm{h}_{M S Y}=\mathrm{rK} / 4$

Dengan memasukkan persamaan (8) dan persamaan (6) ke dalam persamaan fungsi produksi (3) diperoleh biomas/stok ikan pada tingkat MSY :

$\mathrm{X}_{M S Y}=\mathrm{h}_{M S Y} / \mathrm{q} \mathrm{E}_{M S Y}=\mathrm{K} / 2$

Untuk menduga parameter biofisik $r, q$ dan $\mathrm{K}$ dilakukan dengan cara melinearkan persamaan (6) dan menuliskan kembali persamaan (6) menjadi :

$$
\begin{aligned}
& \frac{h}{E}=q K-\frac{q^{2} K}{r} E \\
& U=\alpha-\beta E
\end{aligned}
$$

dimana :

$$
\begin{aligned}
& \mathrm{U}=\text { catch per unit effort (CPUE) } \\
& \alpha=q K, \quad \beta=q 2 \mathrm{~K} / \mathrm{r}
\end{aligned}
$$

Dari series data hasil penangkapan dan upaya penangkapan selanjutnya dengan teknik Ordinary Least Square (OLS) dapat diketahui koefisien $\alpha$ dan $\beta$, namun demikian pendugaan nilai parameter biofisik $r$, $q$ dan $K$ tidak dapat dilakukan, karena dua koefisien regresi tidak dapat menduga tiga parameter biofisik karena masalah curse of dimensionality (Fauzy 2010). Pendugaan parameter biofisik r, q dan $\mathrm{K}$ dapat dilakukan beberapa cara dan salah satunya adalah pendekatan Clarke, Yoshimoto dan Pooley (1992) dan ditulis CYP (Fauzi dan Anna 2005) yang dirumuskan :

$\ln \left(\mathrm{U}_{\mathrm{t}+1}\right)=\frac{2 \mathrm{r}}{2+\mathrm{r}} \ln (\mathrm{qK})+\frac{(2-\mathrm{r})}{(2+\mathrm{r})} \ln \left(\mathrm{U}_{\mathrm{t}}\right)-\frac{\mathrm{q}}{(2+\mathrm{r})}\left(\mathrm{E}_{\mathrm{t}}+\mathrm{E}_{\mathrm{t}+1}\right)$

yang dapat disederhanakan menjadi persamaan :

$$
\ln U_{t+1}=\alpha \ln q K+\beta \ln U_{t}-\gamma\left(E_{t}+E_{t+1}\right)
$$

Persamaan (13), selanjutnya dengan teknik Ordinary Least Square (OLS) dapat diketahui koefisien regresi untuk mendapatkan nilai parameter biofisik sebagai berikut : 
$r=\frac{2(1-\beta)}{(1+\beta)}$

$k=\frac{e^{\frac{\alpha(2+r)}{2 r}}}{q}$

$\mathrm{q}=-\gamma(2+\mathrm{r})$

Untuk menyelesaikan persamaan (12) diperlukan data sekunder: times series hasil tangkapan berupa jenis-jenis ikan demersal dan upaya penangkapan menurut jenis alat tangkap yang digunakan nelayan, yaitu pukat pantai, jaring klitik dan sero. Untuk pendekatan dinamika stok model Schaefer, jenis-jenis ikan yang termasuk dalam kelompok ikan demersal diasumsikan sebagai stok tunggal. Dari data times series ketiga alat tangkap perlu dilakukan standarisasi dengan cara agregasi mengingat adanya perbedaan kemampuan daya tangkap tiap alat. Hasil analisis standarisasi alat tangkap dan print out hasil analisis terhadap persamaan (13) dapat dilihat pada Lampiran 1 dan Lampiran 2.

Selain pendekatan MSY, pendekatan pengelolaan perikanan yang lainnya adalah berdasarkan pendekatan bioekonomi GordonSchaefer, yakni memaksimumkan manfaat ekonomi $\left(\pi_{F}\right)$ atau konsep Maximum Economic Yield, MEY yang dicapai pada kondisi marginal revenue (MR) sama dengan marginal cost $(M C)$, sehingga diperoleh upaya penangkapan $\mathrm{E}_{\text {mey }}$ dan hasil tangkapan, $\mathrm{h}_{\text {mey }}$ untuk model Gordon-Schaefer. Pendekatan MEY dilakukan dengan memasukkan variabel ekonomi berupa harga ikan ( $p$ ) dan biaya penangkapan (c) ke dalam analisis biofisik model Gordon-Schaefer (Fauzi 2010).

$$
\begin{aligned}
\Pi_{F} & =\text { Total Revenue }(T R)-\text { Total Cost }(T C) \\
& =p h(E)-c E
\end{aligned}
$$

Dengan memasukkan persamaan (17) ke dalam persamaan (6) diperoleh persamaan :

$$
\pi=p \cdot\left(q \cdot k \cdot E-\left(\frac{q^{2} \cdot k}{r}\right) \cdot E^{2}\right)-c \cdot E
$$

Dari persamaan (6) dan persamaan (18), selanjutnya diperoleh 3 (tiga) keseimbangan ekonomi statik model bionomik GordonSchaefer:
(1) Keseimbangan open access (OA), terjadi pada kondisi TR=TC atau $\pi=0$. Pada kondisi ini diperoleh nilai-nilai :

$$
\begin{aligned}
& \text { Biomas }\left(\mathrm{X}_{\mathrm{oa}}\right)=\frac{c}{p \cdot q} \\
& \text { Harvest(hoa) }=\left(\frac{\mathrm{r} \cdot \mathrm{c}}{\mathrm{p} \cdot \mathrm{q}}\right)\left(1-\frac{\mathrm{c}}{\mathrm{p} \cdot \mathrm{q} \cdot \mathrm{K}}\right) \\
& \text { Effort(Eoa) }=\frac{\mathrm{r}}{\mathrm{q}}\left(1-\frac{\mathrm{c}}{\mathrm{p} \cdot \mathrm{q} \cdot \mathrm{K}}\right) \\
& \pi \mathrm{oa}=\left(\mathrm{p}-\frac{\mathrm{c}}{\mathrm{p} \cdot \mathrm{x}}\right) \mathrm{F}(\mathrm{x})
\end{aligned}
$$

(2) Keseimbangan MSY, dimana persamaan (6) terjadi pada kondisi $\partial \mathrm{h} / \partial \mathrm{E}=0$. Pada kondisi ini diperoleh nilai-nilai $\mathrm{E}_{M S Y}, \mathrm{~h}_{M S Y}$ dan $\mathrm{X}_{M S Y}$ seperti terlihat pada persamaan (7), (8) dan (9), sedangkan rent ekonomi kondisi MSY adalah :

$$
\pi \mathrm{MSY}=\mathrm{p}\left(\frac{\mathrm{r} \cdot \mathrm{K}}{4}\right)-\mathrm{c} \cdot\left(\frac{\mathrm{r}}{2 \mathrm{q}}\right)
$$

(3) Keseimbangan MEY (Maximum Economic Yield) yang merupakan solusi optimal dalam rezim pengelolaan terkendali. Keseimbangan MEY terjadi pada saat $\partial$ $\pi / \partial \mathrm{E}=0$ atau Marginal Cost $(\mathrm{MC})=$ Marginal Revenue (MR) dengan nilai-nilai yang diperoleh adalah :

$$
\begin{aligned}
& \operatorname{Biomas}\left(\mathrm{X}_{\mathrm{MEY}}\right)=\frac{\mathrm{K}}{2}\left(1+\frac{\mathrm{c}}{\mathrm{p} \cdot \mathrm{q} \cdot \mathrm{K}}\right) \\
& \text { Harvest }\left(h_{M E Y}\right)=\frac{r \cdot K}{4}\left(1+\frac{c}{p \cdot q \cdot K}\right)\left(1-\frac{c}{p \cdot q \cdot K}\right) \\
& \text { Effort }\left(\mathrm{E}_{\mathrm{MSY}}\right)=\frac{\mathrm{r}}{2 \mathrm{q}}\left(1-\frac{\mathrm{c}}{\mathrm{p} \cdot \mathrm{q} \cdot \mathrm{K}}\right) \\
& \pi_{\mathrm{MEY}}=\operatorname{pqKE}\left(1-\frac{\mathrm{q} \cdot \mathrm{E}}{\mathrm{r}}\right)-\mathrm{c} \cdot \mathrm{E}
\end{aligned}
$$

\section{Analisis degradasi sumberdaya ikan}

Dengan diketahuinya ketiga parameter biofisik tersebut, maka dapat dihitung hasil tangkapan lestari, h/estari (persamaan 6) dan selanjutnya dapat diketahui tingkat degradasi ikan, D (Fauzi dan Anna, 2005), dengan haktual adalah hasil tangkapan aktual, melalui persamaan sebagai berikut :

$$
D_{I}=1 /\left(1+e^{\text {hlestari/haktual }}\right)
$$




\section{Pemodelan degradasi dengan sistem dinamik}

Sistem dinamis dapat menggambarkan proses perubahan yang terjadi dari waktu ke waktu. Simulasi yang menggunakan model dinamik, yang merupakan penyederhanaan sistem, dapat memberikan penjelasan tentang proses yang terjadi dalam sistem dan prediksi hasil dari berbagai skenario atau input model. Berdasarkan hasil simulasi model tersebut diperoleh alternatif-alternatif untuk menunjang pengambilan keputusan (Hartisari, 2007). Pemahaman model dengan sistem dinamik untuk memprediksi fenomena degradasi sumberdaya ikan demersal masa mendatang dibangun berdasarkan perubahan dinamika stok model surplus produksi Schaefer. Dinamika stok dipengaruhi oleh laju pertumbuhan ikan dan jumlah stok ikan yang boleh diambil. Laju pertumbuhan stok tergantung dari pertumbuhan intrinsik, daya dukung lingkungan dan jumlah stok itu sendiri, di sisi lain jumlah stok juga mempengaruhi laju pertumbuhan stok. Selain dinamika stok, faktor input upaya penangkapan yang dalam hal ini diasumsikan tetap juga berpengaruh terhadap hasil tangkapan lestari. Sementara itu, degradasi sumberdaya ikan demersal sekitar pantai ditentukan oleh keadaan hasil tangkapan aktual saat kini dan hasil tangkapan lestari yang merupakan hasil tangkapan yang diperbolehkan untuk menjamin ketersediaan sumberdaya.

Dengan demikian, secara sederhana pemodelan dinamik degradasi sumberdaya ikan demersal sekitar pantai di Kabupaten Indramayu terdiri atas subsistem stok (subsistem natural) dan subsistem pemanfaatan sumberdaya (human sistem). Subsistem stok ikan terkait dengan interaksi antara 3 (tiga) parameter biofisik $r, K$ dan $q$ seperti terlihat pada persamaan (5), sedangkan subsistem pemanfaatan sumberdaya ikan terkait dengan interaksi antara variabel stock dan variabel input (jumlah effort). Selanjutnya, degradasi sumberdaya ikan dalam bentuk causal loops dapat dilihat pada Gambar 1.

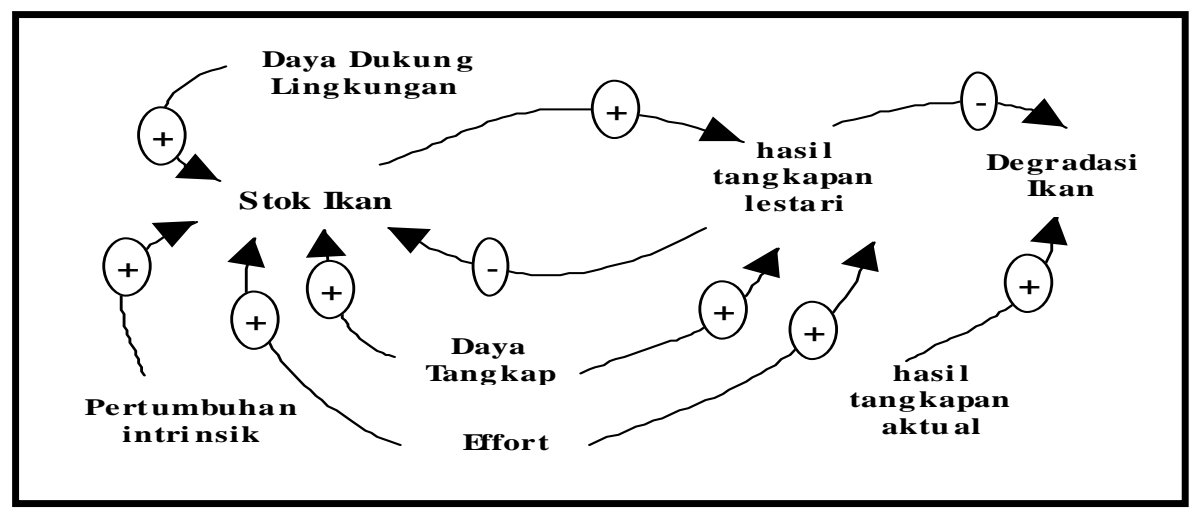

Gambar 1. Diagram lingkar sebab akibat degradasi sumberdaya ikan demersal sekitar pantai

\section{Hasil dan Pembahasan}

Alat tangkap pukat pantai, jaring klitik dan sero digunakan nelayan skala kecil dengan fishing ground di perairan sekitar pantai Kabupaten Indramayu seluas $804 \mathrm{~km}^{2}$ (Lihat Gambar 2). Perikanan demersal sekitar pantai dicirikan dalam situasi akses terbuka (open access fishery). Jenis-jenis ikan yang tertangkap dengan alat tangkap jaring pantai, jaring klitik dan sero yaitu dari famili Leiognathidae (antara lain Leiognathus spp; pepetek), Sciaenidae (antara lain tigawaja, gulamah), Synodontidae (antara lain Saurida tumbil; beloso), Bothidae (antara lain sebelah), Arridae (antara lain Netuma thalassina; manyung), Plotosidae (antara lain sembilang), Nemipteridae (antara lain Nemimterus hexadon; kurisi), Clupeidae (antara lain tembang), Pomadasyidae (antara lain Pomadasys maculatus; gerot-gerot), Polynemoidae (antara lain kurau), Sphyraenoidae (antara lain alu-alu), Lutjanidae (antara lain Lutjanus spp; kakap merah), Hemiramphidae (antara lain julung-julung), Atherinidae (antara lain gerong-gerong), Trichiuridae ((antara lain Trichiurus spp; layur), Latidae (kakap putih) dan Mullidae (antara lain Upenesus sulphureus; kuniran) dan sisanya merupakan jenis-jenis ikan pelagis (antara lain lemuru, layang, ekor kuning, dan ikan kembung), udang, kepiting, rajungan dan kerang-kerangan. Sekitar $76 \%$ dari jenis-jenis ikan yang tertangkap dengan alat tangkap jaring pantai, jaring klitik dan sero merupakan jenis-jenis ikan demersal. 


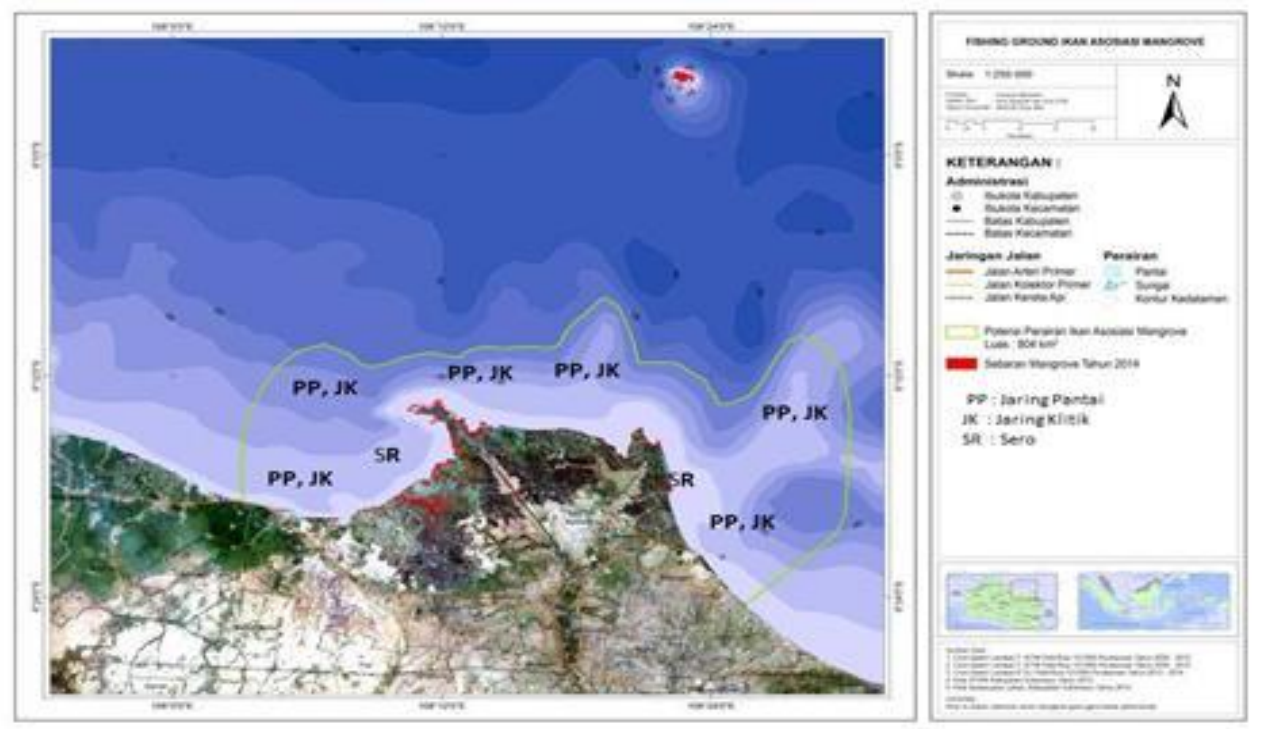

Gambar 2. Area penangkapan ikan alat tangkap pukat pantai, jaring klitik dan sero

Penyelesaian persamaan CYP (lihat Lampiran 2) menghasilkan parameter biofisik untuk $r$ sebesar 1,8359 per tahun, q sebesar 0,0014023344 dan $\mathrm{K}$ sebesar 43.586 ton. Pengelolaan perikanan menurut model keseimbangan MSY (lihat Tabel 1 dan Gambar 3) adalah jumlah $E_{\text {MSY }}$ sebesar 655 unit dan nilai $h_{\text {MSY }}$ sebesar 20.005,38 ton/tahun. Sementara itu, rata-rata upaya penangkapan pada kondisi aktual sebanyak 1.441 unit dengan hasil tangkapan aktual sebesar $20.097,98$ ton. Hal tersebut mengindikasikan bahwa status pengelolaan sumberdaya ikan demersal menunjukan fenomena overfishing. Selain itu, indikasi overfishing dapat dilihat juga rente ekonomi kondisi aktual yang lebih kecil dari rente optimal pada kondisi sole owner atau maximum economic yield (MEY) dan pada kondisi pengelolaan maximum sustainable yield (MSY) (lihat Tabel 1 dan Gambar 3), sehingga menghasilkan selisih rente ekonomi yang besar. Selisih jumlah rente yang besar tersebut disebabkan oleh menurunnya jumlah produksi hasil tangkapan dan dan meningkanya effort, sehingga biaya penangkapan yang dikeluarkan tidak sebanding dengan hasil yang diperoleh.

Tabel 1. Hasil analisis optimasi statik pemanfaatan sumberdaya ikan

\begin{tabular}{lccc}
\hline \multicolumn{1}{c}{ Performa pengelolaan } & \multicolumn{3}{c}{ Model pengelolaan } \\
\cline { 2 - 4 } & Sole Owner / MEY & Open Access/OAY & MSY \\
\hline Biomass (x) (ton) & $23.089,43$ & $2.592,30$ & $21.793,28$ \\
Produksi (h) (ton per tahun) & $19.934,61$ & $4.476,21$ & $20.005,38$ \\
Alat tangkap (unit) & 616 & 1.231 & 655 \\
$\Pi$ (juta Rp per tahun) & 119.028 & 0 & $100.357,51$ \\
\hline
\end{tabular}

Dengan membandingkan antara estimasi hasil tangkapan optimal dengan kondisi hasil tangkapan aktual dapat dikatakan bahwa status pemanfaatan sumberdaya ikan oleh kegiatan perikanan (perikanan jaring pantai, perikanan jaring klitik dan perikanan sero) yang beroperasi di sekitar pantai seluas $804 \mathrm{~km}^{2}$ dengan kepadatan stok 33 ton $/ \mathrm{km}^{2} /$ tahun berada dalam kondisi biologi dan ekonomi overfishing. Kondisi tersebut sesuai dengan kajian Diskanla Kabupaten Indramayu (2014) dengan metode swept area, bahwa tingkat pemanfaatan ikan demersal di Kabupaten Indramayu pada area seluas $2.363 \mathrm{~km}^{2}$ dengan kepadatan stok 20 ton $/ \mathrm{km}^{2} /$ tahun telah mengalami overfishing. Hal ini mengingat potensi lestari (MSY) sebesar 46.243 ton/tahun pada area tersebut di bawah produksi aktualnya (tahun $2010=44.618,20$ ton; tahun $2011=46.830,80$ ton; tahun $2012=48.742,90$ ton dan tahun 2014=59.184,70 ton). Dari Tabel 1 dan Gambar 3 dapat dijelaskan bahwa pengelolaan sole owner atau maximum economic yield (MEY) mempunyai performa yang lebih baik dibandingkan dengan kondisi aktual (pengelolaan saat kini), pengelolaan open access (OA) dan pengelolaan maximum sustainable yield (MSY). Dengan demikian 
kebijakan penurunan upaya penangkapan (uniteffort) perlu dilakukan agar dapat dicapai manfaat yang optimal.

Degradasi sumberdaya dapat diartikan sebagai penurunan nilai dari sumberdaya sebagai dampak dari pemanfaatan sumberdaya tersebut. Hasil tangkapan lestari (h MSY) sebesar 20.005,38 ton per tahun, sedangkan hasil tangkapan aktual sebesar 20.097,98 ton per tahun, maka laju tingkat degradasi adalah 0,2698 . Treshold degradasi diasumsikan terjadi pada saat hasil tangkapan lestari sama dengan hasil tangkapan aktual degradasi, yakni sebesar 0,2689. Dengan demikian dapat dikatakan bahwa sumberdaya ikan demersal mengalami degradasi. Simulasi laju degradasi sumberdaya ikan demersal dilakukan dalam kurun waktu antara tahun 2016 sampai dengan tahun 2030. Dengan asumsi (pada kondisi statusquo) jumlah effort dan parameter biofisik konstan selama periode simulasi serta stok ikan awal pada kondisi MSY, hasil simulasi menunjukkan bahwa sumberdaya ikan demersal tetap mengalami degradasi bila tidak dilakukan kebijakan pengelolaan perikanan yang tepat (Gambar 4). Meskipun stok ikan dijaga pada kondisi MSY, akan tetapi penggunaan jumlah effort yang tidak dikendalikan akan menyebabkan terjadinya fenomena degradasi sumberdaya. Pengaturan effort merupakan salah satu kebijakan perikanan dari sisi input.

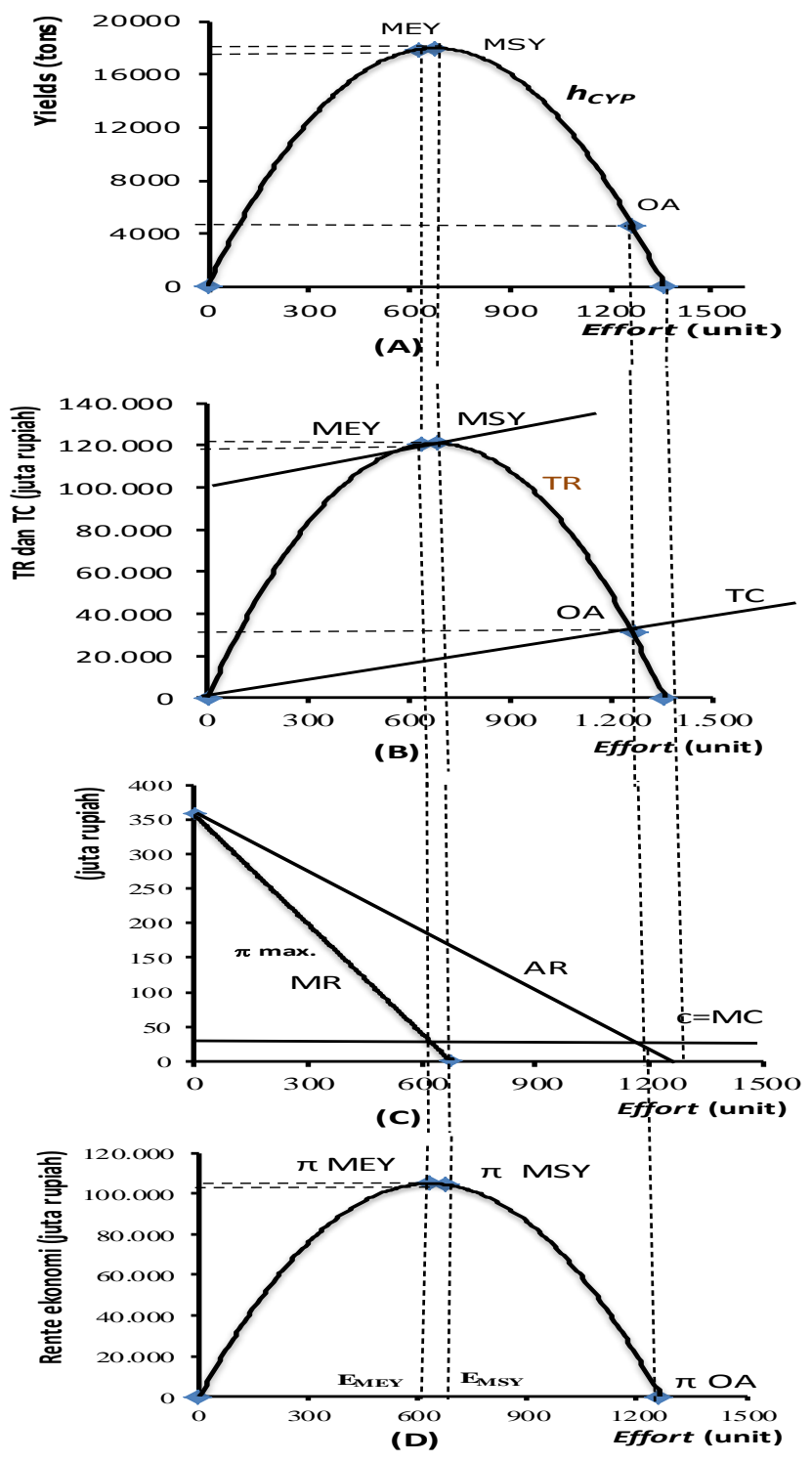

Gambar 3. Keseimbangan bioekonomi statik pengelolaan sumberdaya ikan demersal sekitar pantai 


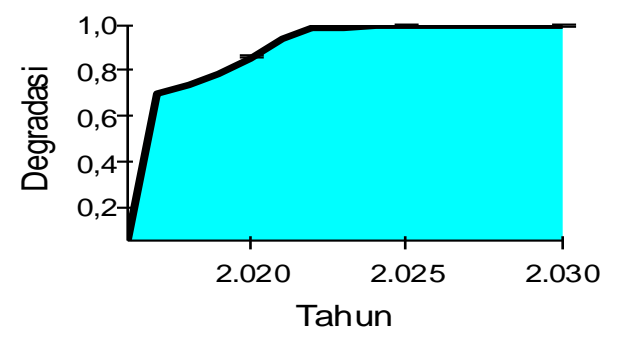

Gambar 4. Hasil simulasi degradasi ikan demersal (kondisi statusquo)

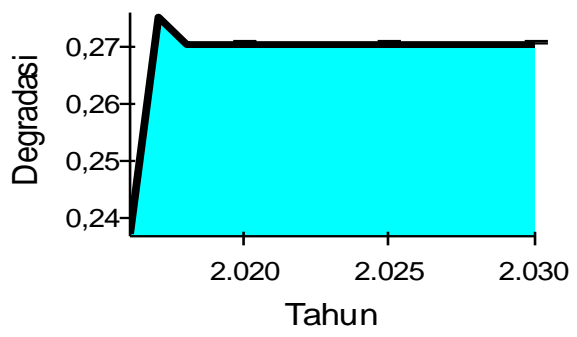

Gambar 5. Hasil simulasi laju degradasi sumberdaya ikan demersal dengan menerapkan kebijakan perikanan melalui pembatasan effort

Dengan mengasumsikan parameter biofisik adalah konstan, selanjutnya dapat dilakukan simulasi kebijakan yang mampu mengendalikan jumlah effort hingga mencapai $\mathrm{E}_{\mathrm{MEY}}$ sejumlah 616 unit atau pengurangan effort sekitar $50 \%$ dari effort aktual diperlukan guna mengatasi persoalan degradasi sumberdaya ikan. Kebijakan perikanan dengan mengurangi jumlah effort untuk mencapai kondisi pengelolaan optimal, $\mathrm{E}_{\mathrm{MEY}}$, akan menurunkan laju degradasi sumberdaya ikan demersal hampir 2,5 kali lipat dari kondisi aktual dan mendekati treshold degradasi (Gambar 5).

\section{Kesimpulan}

Status sumberdaya ikan demersal sekitar pantai di Kabupaten Indramayu menunjukkan overfishing dan terjadinya degradasi sumberdaya. Simulasi laju degradasi sumberdaya ikan demersal sampai dengan tahun 2030 menunjukan masih tetap terjadi degradasi bila tanpa adanya kebijakan perikanan (status quo). Simulasi kebijakan perikanan dengan pengurangan jumlah effort sekitar 2 kali dari kondisi aktual untuk mencapai kondisi pengelolaan optimal akan menurunkan laju degradasi sumberdaya ikan demersal hampir 2,5 kali lipat.

Adanya pengaturan effort perlu disertai kebijakan lainnya, antara lain penciptaan mata pencaharian alternatif dan mengelola habitat ikan dari segala bentuk perusakan. Pengambilan keputusan untuk mengendalikan effort akan mempunyai implikasi sosial ekonomi dan politik yang luas. Oleh karenanya, pengambilan keputusan perlu memperhatikan alternatif lain selain pengurangan effort dengan berbagai kriteria pengambilan keputusan dan adanya kajian institusi dalam implementasi pengaturan upaya penangkapan.

\section{Ucapan Terima Kasih}

Ucapan terima kasih kepada staf Dinas Perikanan dan Kelautan Provinsi Jawa Barat, staf Diskanla Kabupaten Indramayu serta para nelayan yang membantu dalam menyediakan data.

\section{Daftar Pustaka}

Broer, M., Aziz K.A., Widodo J., Djamali A., Ghofar A., Kurnia R. 2001. Potensi, Pemanfaatan dan Peluang Pengembangan Sumberdaya Ikan Laut di Perairan Indonesia. Direktorat Riset dan Eksplorasi Sumberdaya hayati, Direktorat Jenderal Penyerasian Riset dan Eksplorasi Laut, Departemen Kelautan dan Perikanan bekerjasama Komisi Pengkajian Sumberdaya 
Perikanan laut-Pusat Kajian Sumberdaya Pesisir dan Lautan IPB. Bogor. 44 pp.

Charles, A.T. 2001. Sustainable Fishery System. Oxford: Blackwell Science. 367 pp.

Cinner, J.E., McNeil, M.A., Basurto, X., Gelcich, S. 2013. Looking beyond the fisheries crisis: Cumulative learning from smallscale fisheries through diagnostic approaches. Editorial. Global Environ. Change 2 (6) : 1359-1365.

Clarke, R.P., Yoshimoto, S.S., Pooley, S.G. 1992. A Bioeconomic Analysis of the Northwestern Hawaiian Islands Lobster Fishery. Marine Resource Economics 7 :115-140

[Diskanla] Dinas Perikanan dan Kelautan Kabupaten Indramayu. 2014. Studi daerah penangkapan ikan demersal dan ikan pelagis kecil di Kabupaten Indramayu. 112 pp.

Dwiponggo, A. 1987. Indonesia's Marine Fisheries Resources. In Bailey C, Dwiponggo A, Marahudin F. Indonesian Marine Capture Fisheries. ICLARM studies and reviews 10, 196 pp. International Center For Living Aquatic Resources Management, Manila, Phillipinas. Directorate General of Fisheries, and Marine Fisheries Resources Institute, Ministry of Agricultural, Jakarta, Indonesia.

Rahardjo, K. 1991. Arah dan Strategi Pengembangan Perikanan Rakyat. Dalam Prosiding Temu Karya Ilmiah Perikanan Rakyat, Jakarta 18-19 Desember 1989. Buku I. Pusat Penelitian dan Pengembangan Perikanan. Badan Penelitian dan Pengembangan Pertanian. Departemen Pertanian. Jakarta

Ruddle, K., Hickey, E.F.R. 2008. Accounting for the mismanagement of tropical nearshore fisheries. Environment, Development, and Sustainability 10(5): 565-589.

Subani W., Barus, H.R. 1989. Alat Penangkapan Ikan dan Udang Laut di Indonesia (Fishing Gear For Marine Fish and Shrimp in Indonesia. Nomor 50 Th.1988/1989, Edisi Khusus. Jurnal Penelitian Perikanan Laut. Balai Penelitian
Fauzi, A. 2010. Ekonomi Perikanan-Teori, Kebijakan dan Pengelolaa. Jakarta (ID): Gramedia Pustaka Indonesia. 224 pp

Fauzi, A., Anna, S. 2005. Pemodelan Deplesi dan Degradasi Sumberdaya Pesisir dan Laut. Pemodelan Sumberdaya Perikanan dan Kelautan untuk Analisis Kebijakan. Jakarta: PT Gramedia Pustaka Utama. $341 \mathrm{pp}$

Hartisari. 2007. Sistem Dinamik, Konsep Sistem dan Pemodelan Untuk Industri dan Lingkungan. Bogor (ID): Seameo Biotrop. 125 pp

Hilborn, R., Orensanz, J.M. Lobo., Parma, A.M. 2005. Institutions, incentives and the future of fisheries. Philosophical Transaction of the Royal Society B 360 : 47-57.

Nugroho, D., Atmadja, S.B., Nurhakim, S. 2007. Amankah stok sumberdaya ikan laut di indonesia ? Balai Riset Perikanan Laut, Pusat Riset Perikanan Tangkap, Badan Riset Kelautan dan Perikanan, Departemen Kelautan dan Perikanan. Simposium Kelautan dan Perikanan, Jakarta 07 Agustus 2007.

Lackey R.T., 2005. Fisheries: Histroy, Science and Management. pp.121-129. In: Water Encyclopedia: Surface and Agricultural Water, Jay H. Lehr and Jack Keeley, editors, John Wiley and Sons, Inc., Publishers, New York,781 pp.

Perikanan Laut. Badan Penelitian dan Pengembangan Pertanian. Departemen Pertanian. Jakarta. 248 pp.

Schaefer, M.B., 1954 Some aspects of the dynamics of populations important to the management of the commercial marine fisheries. Inter-American Tropical Tuna Commission Bulletin 1(2) :23-56.

Tenriware. 2005. Hubungan antara mesh size bagian bunuhan (crib) dengan selektivitas alat tangkap sero di perairan pantai Pitumpanua Teluk Bone. [tesis]. Bogor (ID): Institut Pertanian Bogor.

Widodo, J., Suadi. 2008. Pengelolaan Sumberdaya Perikanan Laut. Cetakan Kedua. Yogyakarta: Gadjah Mada University Press. 252 pp 
Lampiran 1. Produksi, jumlah trip dan standarisasi alat tangkap pukat pantai (PP), jaring klitik (JK) dan sero (SR)

\begin{tabular}{|c|c|c|c|c|c|c|c|c|c|c|c|}
\hline \multirow{2}{*}{ Tahun } & \multicolumn{4}{|c|}{ Produksi Alat Tangkap, haktual (ton) ${ }^{1)}$} & \multicolumn{3}{|c|}{ Effort, $E$ (unit) ${ }^{1)}$} & \multicolumn{3}{|c|}{$\begin{array}{c}\text { Standarisasi alat tangkap } \\
\left.\text { (unit), Estd }{ }^{2}\right)\end{array}$} & \multirow{2}{*}{$\begin{array}{l}\text { Effort } \\
\text { Standar }\end{array}$} \\
\hline & PP & JK & SR & Total & $\mathrm{PP}$ & JK & $\overline{S R}$ & $\mathrm{PP}$ & JK & SR & \\
\hline 2000 & $5.970,60$ & $3.028,60$ & $1.864,00$ & $10.863,20$ & 268 & 811 & 322 & 268 & 136 & 84 & 488 \\
\hline 2001 & $5.958,50$ & $3.625,50$ & $1.056,00$ & $10.640,00$ & 268 & 811 & 322 & 268 & 163 & 47 & 479 \\
\hline 2002 & $7.434,60$ & $3.168,50$ & $2.802,00$ & $13.405,10$ & 268 & 811 & 322 & 268 & 114 & 101 & 483 \\
\hline 2003 & $6.501,00$ & $6.442,50$ & $2.130,00$ & $15.073,50$ & 288 & 870 & 80 & 288 & 285 & 94 & 668 \\
\hline 2004 & $8.306,00$ & $6.982,00$ & $1.885,00$ & $17.173,00$ & 288 & 870 & 80 & 288 & 242 & 65 & 595 \\
\hline 2005 & $9.903,70$ & $4.772,30$ & 353,00 & $15.029,00$ & 288 & 870 & 180 & 288 & 139 & 10 & 437 \\
\hline 2006 & $13.785,50$ & $7.190,40$ & 390,70 & $21.366,60$ & 288 & 870 & 180 & 288 & 150 & 8 & 446 \\
\hline 2007 & $15.116,30$ & $5.844,60$ & $1.458,80$ & $22.419,70$ & 1.163 & 334 & 78 & 1.163 & 450 & 112 & 1.725 \\
\hline 2008 & $17.148,70$ & $7.560,30$ & $1.675,40$ & $36.384,40$ & 1.162 & 334 & 78 & 1.162 & 512 & 114 & 1.788 \\
\hline 2009 & $18.032,50$ & $16.645,40$ & $1.159,20$ & $35.837,10$ & 1.163 & 334 & 78 & 1.163 & 1.074 & 75 & 2.311 \\
\hline 2010 & $16.860,80$ & $14.384,50$ & $1.378,70$ & $32.624,00$ & 1.173 & 460 & 78 & 1.173 & 1.001 & 96 & 2.270 \\
\hline 2011 & $16.516,40$ & $9.552,60$ & $1.123,90$ & $27.192,90$ & 1.173 & 404 & 78 & 1.173 & 678 & 80 & 1.931 \\
\hline 2012 & $15.341,19$ & $8.176,07$ & $1.430,40$ & $24.947,66$ & 1.461 & 407 & 78 & 1.461 & 779 & 136 & 2.376 \\
\hline 2013 & $14.008,15$ & $6.146,49$ & $1.379,96$ & $21.534,60$ & 1.463 & 409 & 212 & 1.463 & 642 & 144 & 2.249 \\
\hline 2014 & $3.027,41$ & $3.163,89$ & 787,64 & $6.978,94$ & 1.459 & 407 & 225 & 1.525 & 1.477 & 380 & 3.363 \\
\hline Rataan & $11.594,09$ & $7.112,24$ & $1.391,65$ & $20.097,98$ & 812 & 600 & 159 & 812 & 526 & 103 & 1.441 \\
\hline
\end{tabular}

Lampiran 2. Print out analisis regresi persamaan (13) :

Persamaan regresi :

LnCPUEUt+1 = 3,88 - 0,022 LnCPUEUt - 0,000361 EUt+EUt+1

$\begin{array}{lllll}\text { Predictor } & \text { Coef } & \text { SE Coef } & T & P \\ \text { Constant } & 3,884 & 1,627 & 2,39 & 0,036 \\ \text { LnCPUEUt } & -0,0218 & 0,4514 & -0,05 & 0,962 \\ \text { EUt+EUt+1 } & -0,0003609 & 0,0001208 & -2,99 & 0,012\end{array}$

$S=0,477266 \quad R-S q=66,4 \% \quad R-S q(\operatorname{adj})=60,34 \%$

Analysis of Variance
Source
$D F \quad S S \quad M S \quad F \quad P$
$\begin{array}{lllllll}\text { Regression } & 2 & 4,9602 & 2,4801 & 10,89 & 0,002\end{array}$
Residual Error $11 \quad 2,5056 \quad 0,2278$
Total $\quad 13 \quad 7,4658$

Durbin-Watson statistic $=1,36560$ 